Original article

\title{
FLOW CYTOMETRIC ANALYSIS OF SOMATIC CELLS AND OXIDANT/ANTIOXIDANT PROFILE IN DAIRY COWS WITH SUBCLINICAL MASTITIS
}

\author{
N-E. M. AREF ${ }^{1}$, A. S. SAYED ${ }^{1}$, A. M. ZAHRAN ${ }^{2}$, G. A. ABDELAAL ${ }^{3}$ \& E. A. NASSER \\ ${ }^{1}$ Department of Animal Medicine, Faculty of Veterinary Medicine, Assiut \\ University, Assiut, Egypt, ${ }^{2}$ Department of Clinical Pathology, South Egypt Cancer \\ Institute, Assiut University, Assiut, Egypt, ${ }^{3}$ Animal Health Institute, Assiut, Egypt
}

\section{Summary}

Aref, N-E. M., A. S. Sayed, A. M. Zahran, G. A. Abdelaal \& E. A. Nasser, 2018. Flow cytometric analysis of somatic cells and oxidant/antioxidant profile in dairy cows with subclinical mastitis. Bulg. J. Vet. Med., 21, No 3, 347-357.

Flow cytometric analysis of somatic cells count (SCC) and oxidant/antioxidant status of cows with subclinical mastitis (SCM) were investigated in 75 lactating Holstein-Friesian cows (20 controls; 55 SCM cows). Milk from active quarters $(n=280)$ and blood samples $(n=75)$ were aseptically collected. Milk samples were subjected to California Mastitis Test (CMT), microbiologic examination and flow cytometric analysis. Blood and milk samples were analysed for malondialdehyde (MDA) concentrations and total antioxidant capacity (TAC). Microbiological examination revealed 3 major pathogens in a single or mixed infection: Streptococcus species $(26.9 \%)$, Staphylococcus species $(57.7 \%)$ and Escherichia coli $(49.23 \%)$. Flow cytometric analysis showed significant increase $(\mathrm{P}<0.05)$ in inflammatory cells in milk of cows with SCM compared to control cows. Differential SCC was characterised by significant increase $(\mathrm{P}<0.05)$ in polymorphonuclear leukocyte $(\mathrm{PMNL})$ counts compared to normal milk. Additionally, Staphylococcus infection alone or mixed with other lactopathogens resulted in dramatic increase in PMNL. There was a significant decrease $(\mathrm{P}<0.01)$ of TAC in plasma and milk $(0.49 \pm 0.04,0.27 \pm 0.03 \mathrm{mM} / \mathrm{L}$, respectively) and significantly increased $(\mathrm{P}<0.01)$ serum and milk MDA concentrations $(13.72 \pm 0.3,7.72 \pm 0.17 \mathrm{nmol} / \mathrm{mL}$, respectively) in SCM cows. In conclusion, differential SCC is a reliable index for early detection of SCM. Milk PMNL population can be used as a useful indicator for evaluation of udder infection. Additionally, a combination of MDA and TAC can provide complementary information about the health status of udder in dairy farms.

Key words: antioxidant, flow cytometery, mastitis, somatic cell

\section{INTRODUCTION}

Mastitis is well known inflammatory disease of the udder affecting dairy herds, causing devastating economic losses due to reduction of milk production, treatment costs and early culling (Radostits et al., 2007). In dairy cattle, the prevalence of 
subclinical mastitis (SCM) may reach up to $75 \%$ (Kahn \& Line, 2010). Approximately 70 to $80 \%$ of financial losses are caused by SCM (Colla et al., 2011).

The International Dairy Federation (IDF, 1981) has adopted the somatic cell count (SCC) and microbiological status of the milk samples for assessment of the udder health and diagnosis of SCM. However, some logistic, financial and technical concerns associated with microbiological examination of all suspected milk samples, have precluded this technique from being widely implemented (Sharma et al., 2010). While SCC is generally accepted for assessment of the health status of the mammary gland, the SCC results may vary with the status of lactation, age, stress of the animals, time and frequency of milking, and season. Additionally, SCC could not give information about the type of involved cells.

The ultimate identification of individual cell populations of milk leukocytes (lymphocytes, macrophages, and polymorphonuclear leukocytes) using flow cytometry was recently introduced and proposed to give more accurate results than other tests of SCC (Rivas et al., 2001; Koess \& Hamann, 2008).

The involvement of polymorphonuclear leukocytes (PMNL) and macrophages during inflammatory process triggered by pathogens is well documented. The activities of these cells during the early stages of mastitis play a vital role in defense mechanisms against intramammary infection (Abera et al., 2010). Reactive oxygen species (ROS) generated from resident and newly recruited leukocytes during microbial killing process may damage mammary epithelial cells with resultant oxidative stress (Barbano et al., 2006)
Therefore, the present study was carried out to differentiate somatic cells count in milk using flow cytometery for early detection of subclinical mastitis, to screen for the most commonly incriminated lactopathogens, to define a relationship between milk differential somatic cells count and the type of lactopathogens and finally to evaluate the oxidant/antioxidant status of dairy cows with subclinical mastitis.

\section{MATERIALS AND METHODS}

Animals

Seventy five lactating Holstein/Friesian cows were included in the current study, housed in different governmental and private farms within the territory of Assiut Governorate - Egypt. They were apparently healthy after being subjected to general clinical examination according to Rosenberger (1990). Diseased cows, and those affected with clinical mastitis, in early lactation and late pregnancy were excluded from the study.

\section{Samples}

Thirty $\mathrm{mL}$ of milk samples $(\mathrm{n}=280)$ from each quarter were collected aseptically according to the National Mastitis Council (1990). Collected samples were tested by California Mastitis Test (CMT) and transferred immediately to the laboratory for microbiologic, biochemical and flow cytometric analysis.

In addition, blood samples $(5 \mathrm{~mL}$ each) were collected by jugular vein puncture using sterile disposable syringes. A whole blood sample was collected into vacutainer tubes coated with heparin to obtain non-haemolysed clear blood plasma for estimation of total antioxidant capacity. The second blood sample was 
collected into dry, clean centrifuge tube without anticoagulant to obtain nonhaemolysed clear serum for estimation of MDA level.

\section{Clinical, CMT and microbiological examination}

All animals in the study were subjected to general clinical examination according to Rosenberger (1990). California Mastitis Test (CMT) results were read and evaluated with 5 scores:,,,- \pm+++ , and +++ , which are reported as homogenous fluid, very slight flocculation, slight flocculation, flocculation (flaks), and gel formation, respectively (Schalm et al., 1971). Ten mL of milk samples were centrifuged in sterile screw-capped test tubes for 30 min at $3000 \mathrm{rpm}$. The cream and supernatant milk were discarded. Milk sediment was simultaneously cultured on selective media, isolated and identified for major lactopathogens including Staphylococcus, Streptococcus and E. coli. The resulting growth was identified on the basis of morphology, colony characteristics, Gram's reaction and biochemical reactions. Animals culturally positive for at least a single quarter were considered SCM positive.

Flow cytometric analysis of somatic cells

Milk samples were centrifuged for $15 \mathrm{~min}$ at $200 \times \mathrm{g}$ and $4{ }^{\circ} \mathrm{C}$, cream layers and supernatants were discarded and pellets were suspended in phosphate buffered saline (PBS). Cell staining buffer (CSB) up to $\sim 15 \mathrm{~mL}$ was added and centrifuged at $350 \times \mathrm{g}$ for 5 minutes. Pellets were collected and $3 \mathrm{~mL}$ of lysing buffer was added to each tube, kept on ice for $5 \mathrm{~min}$. Cell lysis was stopped by adding $10 \mathrm{~mL}$ $\mathrm{CSB}$, centrifuged for 5 minutes at $1500 \times \mathrm{g}$ for $3 \mathrm{~min}$ at $4{ }^{\circ} \mathrm{C}$, supernatants were discarded and cell pellet was agitated and suspended in $3.5 \mathrm{~mL}$ PBS. Viable cells were counted and resuspended in CSB at $5-10 \times 10^{6}$ cells $/ \mathrm{mL}$ and $100 \mu \mathrm{L} /$ tube of cell suspension $\left(5-10 \times 10^{5}\right.$ cells/tube $)$ was distributed into $12 \times 75 \mathrm{~mm}$ plastic tubes. Surface monoclonal antibodies (mAb) against CD11a and CD18 were obtained from the Monoclonal Antibody Center at Washington State University (Cat. No. BOV2023 recognising CD11a and Cat.; No. BOV2030 recognising CD18) and dispensed into all appropriately labelled tubes. Tubes were agitated gently to mix and incubated in dark for $20 \mathrm{~min}$ at $4{ }^{\circ} \mathrm{C}$. Secondary coloured conjugated monoclonal antibodies, Goat Anti-Mouse IgG1 Alexa Fluor 488, and Goat Anti-Mouse IgG2a, R-Phycoerythrin, (Cat. No. A21121 and Cat. No. P21139, Thermo Fisher Scientific, Rockford, IL, USA) were added, incubated for $30 \mathrm{~min} / 4{ }^{\circ} \mathrm{C}$. Samples were analysed by multicolour flow cytometry (FACS-Caliber, Beckton Dikinson, USA). The flow cytometry was adjusted to count up to 10,000 cells per sample. The percentage of specific cell population was calculated as its proportion to the total number of cells counted by flow cytometry.

\section{Biochemical analysis}

Total antioxidant capacity (TAC) was determined by the reaction of antioxidants in the sample with a defined amount of exogenously provided hydrogen peroxide $\left(\mathrm{H}_{2} \mathrm{O}_{2}\right)$. The antioxidants in the sample eliminated a certain amount of the provided $\mathrm{H}_{2} \mathrm{O}_{2}$. The residual $\mathrm{H}_{2} \mathrm{O}_{2}$ was determined colorimetrically by an enzymatic reaction, which involves the conversion of 3,5, dichloro-2-hydroxy benzensulphonate to a coloured product (Koracevic et al., 2001). The absorbance of the resultant product was measured at $505 \mathrm{~nm}$ wavelength. 
Flow cytometric analysis of somatic cells and oxidant/antioxidant profile in dairy cows with ....

Malondialdehyde (MDA) was determined by measuring thiobarbituric reactive species using the method of RuizLarrea et al. (1994). Thiobarbituric acid (TBA) reacts with MDA in acidic medium at $95{ }^{\circ} \mathrm{C}$ for $30 \mathrm{~min}$ to form thiobarbituric acid reactive product. The absorbance of the resultant pink product was measured at $534 \mathrm{~nm}$ wavelength.

Spectrophotometry (Optizen 3220 UV, Mecasys Co. Ltd, Korea) and standard test kits for TAC and MDA (Biodiagnostica Co-Egypt) were used in both assays.

\section{Statistical analysis}

The SPSS package for Windows version 10.0 was used for statistical analysis (SPSS, 1999). Data were expressed as mean \pm SEM. Differences between groups are determined by means of Student t-test or Duncan's new multiple range test whenever needed. Significance level was set at $\mathrm{P} \leq 0.05$ and $\mathrm{P} \leq 0.01$.

\section{RESULTS}

Analysis of animals' data revealed that the average age, parity and milking period of cows under investigation were 3.9 years, 2.25 parturitions and 3.7 months, respectively. There were no significant differences $(\mathrm{P}>0.05)$ in the age, parity and milking period between control and subclinical mastitis groups. The majority of cows with subclinical mastitis were at the third (42\%) and fourth (45\%) months of lactation.

A total number of 280 quarter milk samples were classified according to CMT into negative $(n=80)$ from 20 healthy cows, one positive $(n=85)$, two positives $(\mathrm{n}=50)$, and three positives $(\mathrm{n}=65)$.

Table 1. Number and frequency of isolated pathogens from milk samples in cows with subclinical mastitis $(\mathrm{n}=130)$

\begin{tabular}{lcc}
\hline \multirow{2}{*}{ Microorganism } & \multicolumn{2}{c}{ SCM milk samples } \\
\cline { 2 - 3 } & Number & Frequency, \% \\
\hline Staphylococcus sp. & 43 & 33.0 \\
Streptococcus sp. & 16 & 12.3 \\
E. coli & 32 & 24.7 \\
\hline Mixed infection & & \\
Staphylococcus + E. coli & 20 & 15.4 \\
Streptococcus + E. coli & 7 & 5.4 \\
Staphylococcus + Streptococcus & 7 & 5.4 \\
Staphylococcus + Streptococcus + E. coli & 5 & 3.8 \\
\hline Total isolates & 130 & 100.0 \\
\hline
\end{tabular}

Table 2. Total antioxidant capacity and malondialdehyde in blood and milk in control cows and cows affected with subclinical mastitis. Data are presented as mean \pm SEM

\begin{tabular}{llcc}
\hline & & Control & Subclinical mastitis \\
\hline \multirow{2}{*}{ Total antioxidants $(\mathrm{mM} / \mathrm{L})$} & plasma $(\mathrm{n}=75)$ & $0.88 \pm 0.10$ & $0.49 \pm 0.04^{*}$ \\
& milk $(\mathrm{n}=280)$ & $0.40 \pm 0.04$ & $0.27 \pm 0.03^{*}$ \\
\hline \multirow{2}{*}{ Malondialdehyde $(\mathrm{nmol} / \mathrm{mL})$} & serum $(\mathrm{n}=75)$ & $4.53 \pm 0.38$ & $13.72 \pm 0.30^{*}$ \\
& milk $(\mathrm{n}=280)$ & $5.27 \pm 0.27$ & $7.72 \pm 0.17^{*}$ \\
\hline
\end{tabular}

* statistically significant difference at $\mathrm{P}<0.01$. 

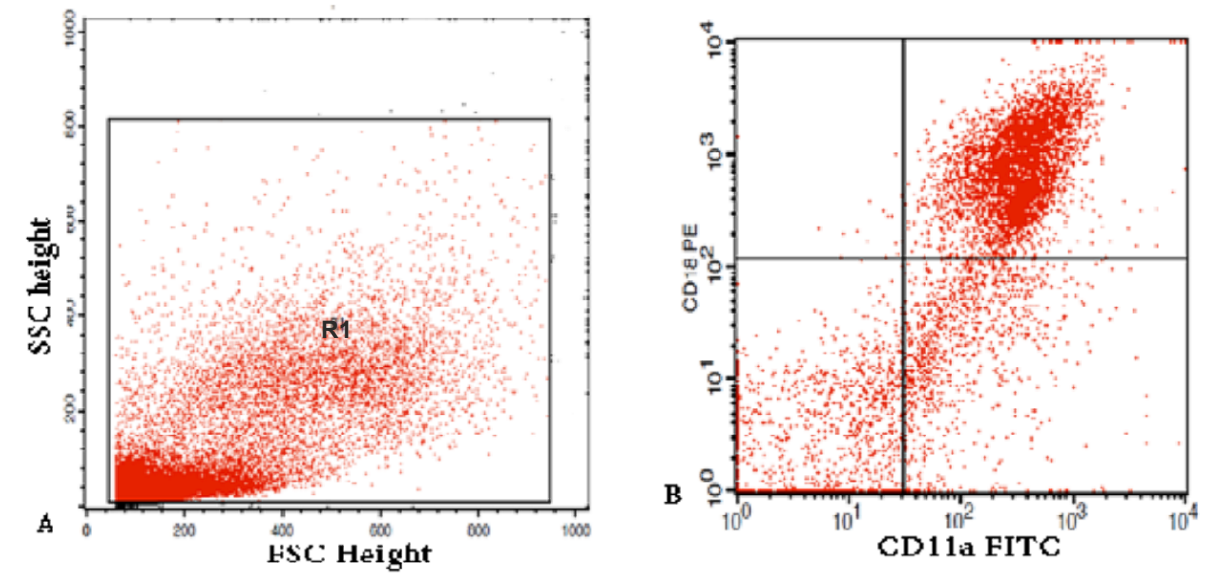

Fig. 1. Flow cytometric analysis of milk leukocytes. Forward (FSC) and side scatter (SSC) histogram was used to define the total somatic cells in milk (R1). Events defined as somatic cells (R1) were then examined for their CD11a and CD18 binding, to detect total leukocyte (the cells that co-express CD18 and CD11a) count.

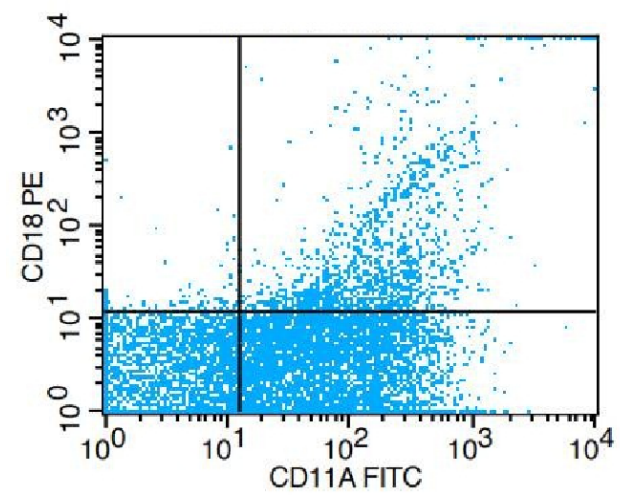

A

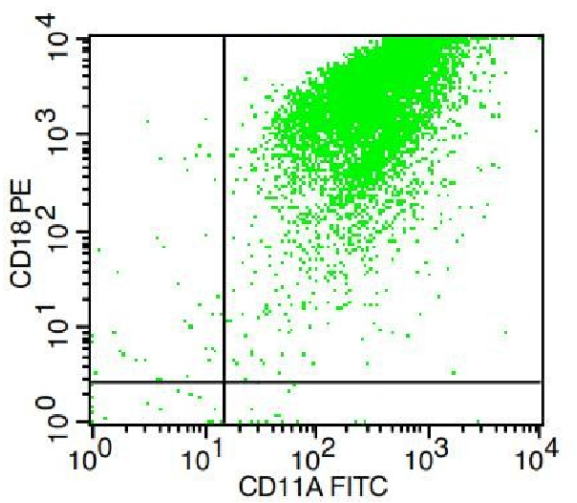

B

Fig. 2. Flow cytometric analysis of control (A) and SCM milk sample (B) with CD11a and CD18 $\mathrm{mAb}$ showing low and high number of inflammatory cells, respectively.

Out of 200 CMT positive milk samples, 130 samples were randomly selected and tested microbiologically. Three microbial pathogens were isolated either alone or in association with other pathogens: Streptococcus species $(\mathrm{n}=35,26.9 \%)$, Staphylococcus species $(\mathrm{n}=75,57.7 \%)$ and Escherichia coli $(\mathrm{n}=64,49.23 \%)$. The frequency of isolation of each pathogen is illustrated in Table 1.
The levels of MDA and TAC in blood and milk of control and subclinical mastitis cows are illustrated in Table 2. There was a significant $(\mathrm{P} \leq 0.01)$ decrease in the milk and plasma TAC and a marked $(\mathrm{P} \leq 0.01)$ increase in the milk and serum level of MDA in cows with subclinical mastitis compared to healthy cows. 


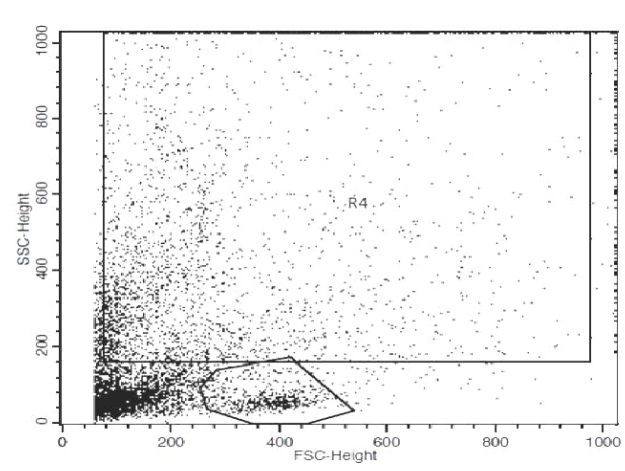

A

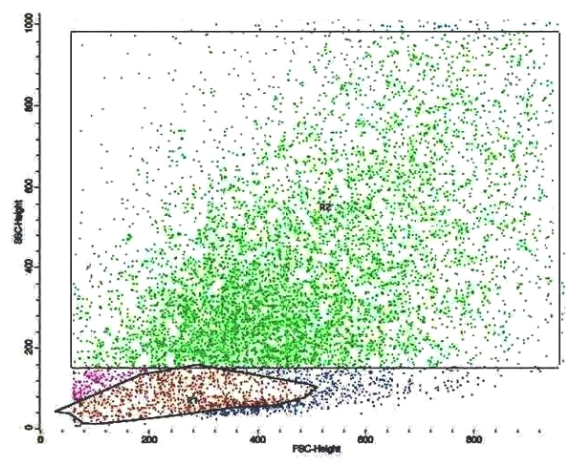

B

Fig. 3. Flow cytometric analysis of control and subclinical mastitis samples with CD11a and CD18 $\mathrm{mAb}$ showing predominant fields of lymphocytes (A) and neutrophils (B).

Table 3. Inflammatory and non-inflammatory cells in milk of control cows and cows affected with subclinical mastitis (mean \pm SEM and percentage)

\begin{tabular}{lcc}
\hline & Control $(\mathrm{n}=5)$ & Subclinical mastitis $(\mathrm{n}=45)$ \\
\hline \multirow{2}{*}{ Inflammatory cells } & $1045 \pm 312.8$ & $5337.6 \pm 422.5^{*}$ \\
& $(14.5 \pm 4.1 \%)$ & $(71.4 \pm 4.2 \%)$ \\
\hline \multirow{2}{*}{ Neutrophils } & $786.33 \pm 176.50$ & $3696.4 \pm 1502.12^{*}$ \\
& $(8.66 \pm 0.96 \%)$ & $(44.2 \pm 17.43 \%)$ \\
\hline \multirow{2}{*}{ Lymphocytes } & $2252.67 \pm 1694.9$ & $1285.7 \pm 1098.13^{*}$ \\
& $(22.84 \pm 16.45 \%)$ & $(14.69 \pm 10.1 \%)$ \\
\hline \multirow{2}{*}{ Non-inflammatory cells } & $6106.7 \pm 1167.1$ & $2180.9 \pm 409.4^{*}$ \\
& $(85.5 \pm 4.1 \%)$ & $(28.2 \pm 4.2 \%)$ \\
\hline
\end{tabular}

* statistically significant difference at $\mathrm{P}<0.05$

Table 4. Inflammatory and non-inflammatory cells in milk of control cows and cows with subclinical mastitis in relation to lactopathogens (mean \pm SEM and percentage)

\begin{tabular}{lccc}
\hline & \multicolumn{2}{c}{ Non-inflammatory cells } & \multicolumn{2}{c}{ Inflammatory cells } \\
\cline { 2 - 4 } & \multicolumn{1}{c}{ Count } & Count & $\%$ \\
\hline Control & $6106.70 \pm 1146.88$ & $1045.00 \pm 312.80$ & $14.50 \pm 4.10$ \\
\hline Subclinical mastitis & $2756.83 \pm 892.10$ & $4949.80 \pm 745.50$ & $62.27 \pm 8.50$ \\
Staphylococcus sp. & $2649.50 \pm 201.50$ & $3160.50 \pm 211.80$ & $52.39 \pm 6.90$ \\
Streptococcus sp. & $2832.33 \pm 345.60$ & $3828.70 \pm 645.77$ & $56.81 \pm 10.86$ \\
E. coli & & & \\
\hline Mixed infection & $1391.56 \pm 390.47$ & $6365.44 \pm 457.95$ & $82.06 \pm 4.02$ \\
Staphylococcus + E. coli & $5040.33 \pm 1032.50$ & $4330.00 \pm 732.87$ & $45.21 \pm 14.62$ \\
Streptococcus + E. coli & $117.50 \pm 47.98$ & $8409.00 \pm 587.14$ & $97.67 \pm 6.41$ \\
Staphylococcus + & Streptococcus + E. coli & &
\end{tabular}


Leukocyte population were determined by flow cytometry and calculated as positive cells (labelled) by the CD11a/ CD18 $\mathrm{mAb}$. Epithelial cells were calculated as the negative cells (not labelled) by CD11a/ CD18 mAb. The location of positive cells labelled with mAb used on the dot plot [Forward-angle light scatter (FSC) by logarithm side-light scatter (SSC)] map is presented on Fig. 1-3.

Quarters free of intramammary infection had significantly increased CD11a/ CD18 negative cells and were reported as non-inflammatory cells. Additionally, healthy udder showed a higher population of lymphocyte than that reported in SCM based on the location of predominant cells on the flow cytometric scatter (low FSC and SSC) (Fig. 2A). On the other hand, flow cytometric analysis of somatic cells revealed significant $(\mathrm{P} \leq 0.05)$ increase in leukocytes (inflammatory) cells in milk of cows with SCM compared to control ones (Fig. 2B, Table 3). A dramatic increase in leukocyte population was reported in SCM cases due to Staphylococcus infection either alone or in mixed infection (Table 4).

\section{DISCUSSION}

Somatic cells count in milk has been adopted in mastitis control programmes and milk quality control; however, some physiological factors such as status of lactation, age, stress, time and frequency of milking, and season may negatively affect the SCC. Moreover, SCC could not give information about the type of involved cells (inflammatory and noninflammatory). Differential somatic cell count (DSCC) provides more detailed evaluation of the udder health status (Schwarz et al., 2011) and allows for early detection of mastitis.
The receptors of CD11a and CD18 are distributed on various immune cells including T, B and NK cells, macrophages and granulocytes (Larson \& Springer, 1990). In this study, immune and nonimmune cells (epithelial cells) were identified by flow cytometry using specific monoclonal antibody against CD11a/ CD18 receptors. Epithelial cells were identified as the negative cells to the mAb anti-CD11a/CD18 receptor whereas positive cells on dot plot of FC scatter were identified as lymphocytes and neutrophils. Fig. 1-2A showed forward (FSC) and side scatter (SSC) histogram that used to define SCC and differentiate milk leukocytes (lymphocytes and granulocytes) according to their size and complexity. Lymphocytes were characterised by their small size (low forward scatter) and lower complexity and granulations (low side scatter) while granulocytes - by their large size (high forward scatter) and higher complexity and granulations (high side scatter) at the total somatic cells in milk.

Our results showed that milk samples from culture-negative udders revealed high epithelial cells and lymphocyte percentages of $85.5 \pm 4.1 \%$ and $22.84 \pm 16.45 \%$, respectively while PMNL were $8.66 \pm$ $0.96 \%$. Similar observations were reported in previous studies (Rivas et al., 2001; Schwarz et al., 2011).

On the other hand, inflammation is generally defined as increased leukocytes, especially PMNL in tissues or body fluids in response to pathogens. An increased transfer of PMNL from blood into the area of infection at the beginning of an inflammation is well documented and could be detected (Kehrli \& Shuster, 1994; Paape et al., 2002). Therefore, a high PMNL percentage in milk is accepted as an important indicator of inflammatory reaction (Pillai et al., 2001; 
Paape et al., 2002). The obtained results of flow cytometric analysis of somatic cells revealed a significant increase $(\mathrm{P}<0.05)$ in inflammatory cells in milk of cows with SCM (71.4 $\pm 4.2 \%)$ compared with apparently healthy cows (Fig. 2b). Most of these positive cells (labelled CD11a/CD18) were defined as PMNL on the dot plot flow cytometric position (PMNL gate, high FSC and SSC) (Fig. 3). Milk of cows with SCM showed a significant increase $(\mathrm{P}<0.05)$ in neutrophils counts and percentage compared to control milk (negative CMT). PMNL were the dominant cell population with significant average share $(44.2 \pm 17.43 \%)$ among tested SCM samples compared with control milk. Similar findings have been previously reported in cattle and buffaloes (Zaman et al., 2009; Hussein et al., 2012). Abera et al. (2010) stated that neutrophils are the predominant cell type found in mammary tissues and secretions during inflammation and might constitute more than $90 \%$ of total mammary gland leukocytes. The increase in SCC is mainly due to the migration of PMNL that are essential components of the innate immunity (Boutet et al., 2004) as they form the first line of defense against bacterial infections. The essential role of the CD11a/ CD18 receptors as adherence molecules is well documented (Tizard, 1996). Normally, neutrophils float freely in the blood and do not bind to endothelial cells. As a result of challenge with a lactopathogen, resident macrophages ingest bacteria and secrete unidentified mediators. In the next step, surface expression of the integrin CD11a/CD18 increased, inflammatory cells adhere to endothelial cells and transmigrate to the area of infection. Therefore, DSCC enables one to detect mastitis in its initial phase and could be used successfully to monitor udder health.
A significantly decrease in the proportion of lymphocytes and non-inflammatory cells in SCM was recorded. Similarly, lymphocyte, monocyte and macrophage population were significantly decreased in the milk of infected animals (Gargouri et al., 2008; Hussein et al., 2012).

Data of flow cytometry demonstrated an interesting relationship between the DSCC and type of infection. It seems that the proportion of the cell types, or subtypes, rather than their total number, was a factor defining the type of the lactopathogen. Flow cytometric data screening showed various degree of significant increase in neutrophils in relation to type of lactopathogens. The highest proportion of inflammatory cells was reported in milk from quarters infected by Staphylococcus alone or in association with other lactopathogens. The results of the present study strongly suggested the existence of a correlation between the immune response and different mastitic pathogens. It also emphasized the importance of studying the particular leukocyte population patterns for each pathogen. Similar observations were reported in previous studies (Soltys \& Quinn, 1999; Fitzpatrick, 2001).

The influx of inflammatory cells, primarily PMNL, into the udder tissue in response to infection helps destroying the invading bacteria by oxygen-dependent and oxygen-independent systems. Concurrently, they potentially damage the secretory epithelium of mammary gland by reactive oxygen species (ROS) and proteolytic enzymes (Knaapen et al., 1999; Hamed et al., 2008). The determination of lipid peroxidation status via assessment of MDA is among the most widely used methods for determination of the oxidative stress (Kohen \& Nyskaa, 2002). The present study revealed a significant increase $(\mathrm{P}<0.01)$ in the plasma and milk 
concentration of MDA in cows with SCM compared to normal cows. Similar results have been reported in other studies on dairy cows (Suriyasathaporna et al., 2006; Andrei et al., 2010; Yang et al., 2011). In contrast, Ranjan et al. (2005) and Kizil et al. (2007) reported an enhanced erythrocyte and plasma lipid peroxide content in clinical, but not in subclinical mastitis cases. On the other hand, concentration of TAC showed a significant decrease $(\mathrm{P}<0.01)$ in milk and blood samples of subclinically mastitic compared to normal cows. The high production of MDA and low levels of TAC in SCM milk reported in this study confirmed the occurrence of a process of auto-oxidation and oxidative stress associated with SCM in dairy cows. Similar results have been reported in previous studies (Suriyasathaporna et al. 2006; Atakisi et al., 2010).

Total antioxidant capacity identifies a wide range of all activities of the measurable exogenous and endogenous antioxidants (Somogyi et al., 2007). TAC consumption by generated ROS leads to oxidative stress and resultant reduction in milk production. There is a significant negative correlation between the TAC and total oxidant capacity (TOC) values (Erel, 2005).

It can be concluded that differential somatic cell count was the most reliable index for early detection of SCM next to bacteriological examination. Neutrophil population in milk can be used a useful indicator in the evaluation of mammary gland infection. Additionally, a combination of MDA and TAC can provide complementary information about the health status of udder in dairy farms.

\section{REFERENCES}

Abera, M., B. Demie, K. Aragaw, F. Regassa, \& A. Regassa, 2010. Isolation and identi- fication of Staphylococcus aureus from bovine mastitic milk and their drug resistance patterns in Adama Town, Ethiopia. Journal of Veterinary Medicine and Animal Health, 2, 29-34.

Andrei, S., S. Matei, D. Zinveliu, A. Pintea, A. Bunea, S. Ciupe, \& I. Groza, 2010. Correlations between antioxidant enzymes activity and lipids peroxidation level in blood and milk from cows with subclinical mastitis. Bulletin of University of Agricultural Sciences and Veterinary Medicine ClujNapoca, 67, 6-11.

Atakisi, O., O. H. Hasan, E. Atakisi, O. Merhan, S. M. Pancarci, A. Ozcan, S. Marasli, B. Polat, A. Colak \& S. Kaya, 2010. Subclinical mastitis causes alterations in nitric oxide, total oxidant and antioxidant capacity in cow milk. Research in Veterinary Science, 89, 10-13.

Barbano, D. M., Y. Ma \& M. V. Santos, 2006. Influence of raw milk quality on fluid milk shelf life. Journal of Dairy Science, 89, E15-E19.

Boutet, P., D. Boulanger, L. Gillet, A. Vanderplasschen, R. Closset, F. Bureau \& P. Lekeux, 2004. Delayed neutrophil apoptosis in bovine subclinical mastitis. Journal of Dairy Science, 87, 4104-4114.

Colla, M. F., S. F. Valle, P. Secchi, N. Duda, M. Scalon, J. W. Dürr \& F. H. Diaz González, 2011. Plasma haptoglobin values in cows with different somatic cell counting in milk samples. Acta Scientiae Veterinariae, 39, 944-949.

Erel, O., 2005. A new automated colorimetric method for measuring total oxidant status. Clinical Biochemistry, 38, 1103-1111.

Fitzpatrick, L. J., 2001. Milk somatic cells what do they do? In: Proceedings of the British Mastitis Conference, Garstang, Institute for Animal Health/Milk Development Council, pp. 56-62.

Gargouri, A., H. Hamed \& A. El Feki, 2008. Total and differential bulk cow milk somatic cell counts and their relation with lipolysis. Livestock Science, 113, 274-279. 
Flow cytometric analysis of somatic cells and oxidant/antioxidant profile in dairy cows with ....

Hamed, H., A. El Feki \& A. Gargouri, 2008. Total and differential bulk cow milk somatic cell counts and their relation with antioxidant factors. Comptes Rendus Biologies, 331, 144-151.

Hussein, S. A., 2012. Prevalence and bacterial etiology of subclinical mastitis in dairy cows in Al Sulaimaniyah district, Kufa Journal of Veterinary Medical Sciences, 3, 190-203.

IDF (International Dairy Federation), 1981. Laboratory Methods for Use in Mastitis Work, Document 132, Brussels, Belgium.

Larson, R. S. \& T. A. Springer, 1990. Structure and function of leukocyte integrins. Immunological Reviews, 114, 181-217.

Kahn, C. M. \& S. Line, 2010. The Merck Veterinary Manual, $10^{\text {th }}$ edn, Merck and Co., USA. pp. 1248-1257.

Kehrli, M. E. \& D. E. Shuster, 1994. Factors affecting milk somatic cells and their role in health of the bovine mammary gland. Journal of Dairy Sciences, 77, 619-627.

Kizil, O., Y. Akar, N. Saat, M. Kizil \& M. Yuksel, 2007. The plasma lipid peroxidation intensity (MDA) and chain-breaking antioxidant concentrations in the cows with clinic or subclinic mastitis. Revue de Médecine Vétérinaire, 158, 529-533.

Knaapen, A. M., F. Seiler, P. A. Schilderman, P. Nehls, J. Bruch, R. P. Schins \& P. J. Borm, 1999. Neutrophils cause oxidative DNA damage in alveolar epithelial cells. Free Radical Biology and Medicine, 27, 234-240.

Koess, C. \& J. Hamann, 2008. Detection of mastitis in the bovine mammary gland by flow cytometry at early stages. Journal of Dairy Research, 75, 225-232.

Kohen, R. \& A. Nyska, 2002. Oxidation of biological systems: Oxidative stress phenomena, antioxidants, redox reactions, and methods for their quantification. Journal of Toxicologic Pathology, 30, 620-650.

Koracevic, D., G. Koracevic, V. Djordjevic, S. Andrejevic \& V. Cosic, 2001. Method for the measurement of antioxidant activity in human fluids. Journal of Clinical Pathology, 54, 356-361.

National Mastitis Council (NMC), 1990. Microbiological Procedures for the Diagnosis of Udder Infection. $3^{\text {rd }}$ edn, Arlington V.A. National Mastitis Council Inc.

Paape, M. J., J. Mehrzad, X. Zhao, J. Detilleux \& C. Burvenich, 2002. Defense of the bovine mammary gland by polymorphonuclear neutrophil leukocytes. Journal of Mammary Gland Biology and Neoplasia, 7, 109-121.

Pillai, S. R., E. Kunze, L. M. Sordillo \& B. M. Jayarao, 2001. Application of differential inflammatory cell count as a tool to monitor udder health. Journal of Dairy Science, 84, 1413-1420.

Radostits, O. M., C. C. Gay, K. W. Hinchcliff \& P. D. Constable, 2007. Veterinary Medicine. A Textbook of the Diseases of Cattle, Horses, Sheep, Pigs and Goats, $10^{\text {th }}$ edn, Saunders Elsevier, Edinburgh, pp. 673-759.

Ranjan, R., D. Swarup, R. Naresh \& R. C. Patra, 2005. Enhanced erythrocytic lipid peroxides and reduced plasma ascorbic acid, and alteration in blood trace elements level in dairy cows with mastitis. Veterinary Research Communications, 29, 2734.

Rivas, A. L., F. W. Quimby, J. Blue \& O. Coksaygan, 2001. Longitudinal evaluation of bovine mammary gland health status by somatic cell counting, flow cytometry, and cytology. Journal of Veterinary Diagnostic Investigation, 13, 399-407.

Rosenberger, G., 1990. Clinical Examination of Cattle. Velage Paul Parey. Berlin and Hamburg, pp 120-138.

Ruiz-Larrea, M. B., A. M. Leal, M. Liza, M. Lacort \& H. De Groot, 1994. Antioxidant effects of estradiol and 2-hydroxyestradiol on iron-induced lipid peroxidation of rat liver microsomes. Steroids, 59, 383-388.

Schalm, O. W., E. Carrol \& N. C. Jain, 1971. Bovine Mastitis, $1^{\text {st }}$ edn, Lea and Febiger, Philadelphia, USA. 
Schwarz, D., U. S. Diesterbeck, S. Koenig, K. Bruegemann, K. Schlez, M. Zschoeck, W. Wolter \& C. P. Czerny, 2011. Flow cytometric differential cell counts in milk for the evaluation of inflammatory reactions in clinically healthy and subclinically infected bovine mammary glands. Journal of Dairy Science, 94, 5033-5044.

Sharma, N., V. Pandey \& N. A. Sudan, 2010. Comparison of some indirect screening tests for detection of subclinical mastitis in dairy cows. Bulgarian Journal of Veterinary Medicine, 13, 98-103.

Soltys, J. \& M. T. Quinn, 1999. Selective recruitment of T-cell subsets to the udder during staphylococcal and streptococcal mastitis: analysis of lymphocyte subsets and adhesion molecule expression. Infection and Immunity, 67, 6293-6302.

Somogyi, A., K. Rosta, P. Pusztai, Z. Tulassay \& G. Nagy, 2007. Antioxidant measurements. Physiological Measurement, 28, 41-55.

Suriyasathaporna, S., U. Vnitketkumnuenb, T. Chewonarinb, S. Boonyayatraa, K. Kreausukona \& Y. H. Schukken, 2006. Higher somatic cell counts resulted in higher malondialdehyde concentration in raw cow's milk. International Dairy Journal, 16, 1088-1091.
Tizard, R. I., 1996. Veterinary Immunology, Chapter 5, W.B. Saunders, Philadelphia, pp. 43-54.

Yang, F. L., X. S. Li, B. X. He, X. L. Yang, G. H. Li, P. Liu, O. H. Huang, X. M. Pan \& J. Li, 2011. Malondialdehyde level and some enzymatic activities in subclinical mastitis milk. African Journal of Biotechnology, 10, 5534-5538.

Zaman, M., S. Khan, M. Avais, M. Ijaz, J. A. Khan \& A. Khan, 2009. Estimation of protein, total leukocyte count and differential leukocyte count in the blood and milk of subclinically mastitic buffaloes. Pakistan Journal of Zoology, 9, 115-118.

Paper received 25.11.2016; accepted for publication 06.02.2017

\section{Correspondence:}

Nasr-Eldin M. Aref

Department of Animal Medicine

Faculty of Veterinary Medicine

Assiut University

Assiut 71526, Egypt

tel. +201060024252

e-mail: nasreldeen.aref@vet.au.edu.eg 